\title{
SADRANAN SEBAGAI BENTUK KOMUNIKASI SOSIAL
}

\author{
Hanun Wuryansari, Puji Lestari, dan Isbandi \\ Program Studi Ilmu Komunikasi Universitas Pembangunan Nasional "Veteran" \\ Yogyakarta, Jl. Babarsari No.2 Tambakbayan Yogyakarta 55282, Telp. (0274) \\ 485268, HP: 087839037461, Email: hanun.w@gmail.com
}

\begin{abstract}
This research aims to identify the form of social communication in Sadranan ceremony tradition. Research method that uses for collecting data are qualitative descriptive with interview, observation, documentation and study literature. Data are analyzed using validity techniqueas triangulated-source. This research investigates pre-procession, performance and post-ceremonial of Sadranan. Values that presented in Sadranan ceremonial consist of kinship and mutual-help. The discussion is refers to Theory of Symbol, Cultural Theory, and Interaksionisme simbolis by. Conclusions that can be drawn are Sadranan ceremony, as a symbol has dual concept namely general concept as grave-pilgrimage and specific concept as thankfulness to God the One, welcoming Ramadhan, praying forgiveness for ancestor spirit, and maintaining social relation during Sadranan procession. Sadranan ceremony is one of communication element with urges people to meet and communicate. Sadranan ceremony as native costum remain performed till nowadays and develops which represent native custom particularly Karangturi village. It is also concluded that Sadranan ceremony has be through value modification which inserted with Islam principles.
\end{abstract}

Keyword: Ceremony, Sadranan, Social Communication.

\begin{abstract}
Abstrak
Tujuan penelitian ini adalah untuk mengidentifikasi bentuk komunikasi sosial di upacara tradisi Sadranan. Metode penelitian yang digunakan untuk mengumpulkan data adalah deskriptif kualitatif dengan wawancara, observasi, dokumentasi dan studi pustaka. Data dianalisis menggunakan teknik validitas triangulasi-sumber. Penelitian ini menyelidiki pra-prosesi, kinerja dan pasca-upacara Sadranan. Nilai-nilai yang disajikan dalam upacara Sadranan diantaranya kekeluargaan dan sikap tolong-menolong. Penelitian ini mengacu pada Teori Symbol, Teori Budaya, dan Interaksionisme simbolis. Kesimpulan yang dapat ditarik adalah upacara Sadranan, sebagai simbol yang memiliki konsep ganda yaitu konsep umum sebagai kuburan-haji dan konsep sebagai rasa syukur kepada Tuhan, menyambut Ramadhan, berdoa pengampunan bagi roh leluhur, dan memelihara hubungan sosial selama prosesi Sadranan. Upacara Sadranan adalah salah satu elemen komunikasi dengan mendesak orang-orang untuk bertemu dan berkomunikasi. Upacara Sadranan sebagai budaya asli yang tetap dilakukan sampai saat ini dan mengembangkan adat asli desa Karangturi. Dapat disimpulkan juga bahwa upacara Sadranan telah melalui modifikasi nilai yang dimasukkan dengan prinsip Islam.
\end{abstract}

Kata kunci: Upacara, Sadranan, Komunikasi Sosial 


\section{Pendahuluan}

Setiap suku bangsa memiliki kebudayaan sendiri-sendiri yang berbedabeda antara budaya satu dengan budaya yang lain. Demikian pula dengan suku Jawa. Suku Jawa memiliki kebudayaan yang khas dimana di dalam metode budayanya digunakan simbol-simbol sebagai sarana atau media komunikasi untuk menyampaikan pesan bagi bangsa atau penerusnya. Budaya yang terdapat dalam suatu lingkungan masyarakat beraneka ragam dan bervariasi. Hal tersebut bersifat turun-temurun dari generasi ke generasi. Budaya yang sudah diyakini sejak dulu itu hingga kini dijadikan sebagai suatu hal yang harus dilakukan secara terus menerus dari generasi ke generasi. Di zaman modern seperti sekarang ini, kebudayaan masyarakat Jawa yang cenderung mengandung unsur mistik tidak bisa ditinggalkan begitu saja. Karena hal tersebut dianggap tidak menghormati warisan para orang terdahulu atau leluhur.

Budaya itu sendiri diyakini sebagai hasil tingkah laku atau kreasi manusia, memerlukan bahan materi atau alat penghantar untuk menyampaikan maksud. Medium budaya itu dapat berupa bahasa, benda, warna, suara, tindakan yang merupakan simbol-simbol budaya. Budaya Jawa yang dikatakan edi penidan adi luhung, karena telah terbina selama berabad-abad lamanya (Herusasoto, 2001:78).

Penggunaan simbol dalam suatu budaya merupakan media yang berasal dari nenek moyang untuk melukiskan segala macam bentuk pesan pengetahuan pada masyarakat sebagai generasi penerus. Adanya simbol yang melekat pada suatu adat ataupun kebudayaan diharapkan dapat member pemahaman bagi masyarakat penggunanya. Salah satu tindakan simbolis yang sampai saat ini masih diyakini serta dilestarikan oleh masyarakat Jawa adalah upacara tradisional.

Upacara tradisional merupakan sesuatu yang sudah tidak asing lagi bagi seluruh masyarakat dunia. Upacara tradisional merupakan suatu kegiatan resmi yang dilakukan untuk peristiwa-peristiwa tertentu. Kegiatan tersebut mempunyai kaitan dengan sebuah kepercayaan mengenai adanya kekuatan di luar kemampuan manusia. Yang dimaksud dengan kekuatan di luar manusia adalah Tuhan Yang Maha Esa.

Upacara tradisional dapat juga dikatakan sebagai suatu kegiatan yang dilakukan pada saat tertentu dan secara teratur yang di dalamnya terdapat pengaktifan simbol-simbol komunikasi. Upacara tradisional digunakan sebagai perantara dalam menyampaikan pesanpesan yang terkandung dalam simbolsimbol komunikasi dimana di dalamnya terdapat hal-hal yang wajib dimengerti oleh masyarakat penggunanya.

Simbolisme sangat menonjol peranannya dalam tradisi atau adat istiadat. Simbolisme ini kentara sekali dalam upacara-upacara adat yang merupakan warisan turun-temurun dari generasi yang tua ke generasi yang berikutnya yang lebih muda. Simbolisme ini diperagakan mulai dari upacara saat bayi masih dalam kandungan ibunya, saat ia dilahirkan ke dunia sampai saat upacara kematiannya. Bahkan pada beberapa suku bangsa di Indonesia upacara-upacara itu masih dilanjutkan lagi sampai beberapa waktu setelah jenazah dikebumikan. Di Jawa peringatan Selamatan bagi yang meninggal dilakukan sampai tahun kelima menurut hitungan tarikh Jawa.

Littlejohn (1996:64) mengungkapkan bahwa simbol adalah basis dari seluruh proses komunikasi. Manusia dengan perantara simbol dapat melakukan komunikasi dengan sesamanya dan sebaliknya, tanpa perantara simbol komunikasi, manusia tidak bisa melakukan 
komunikasi. Susanne Langer (Littlejohn, 1999:68) menyatakan bahwa di dunia ini banyak sekali simbol-simbol komunikasi, salah satu simbol-simbol komunikasi yang ada di dunia ini adalah uapacara adat (worship) dan merupakan perwujudan kebudayaan.

Simbol berasal dari kata Yunani symbolos yang berarti tanda atau ciri yang memberitahukan sesuatu hal pada seseorang. Kamus Umum Bahasa Indonesia susunan W.J.S. Poerwadarminta mengartikan: simbol atau lambang ialah sesuatu seperti tanda, lukisan, perkataan, lencana dan sebagainya,yang menyatakan sesuatu hal atau mengandung maksud tertentu, misalnya warna putih ialah lambang kesucian, gambar padi sebagai lambang kemakmuran; atau berarti juga tanda pengenal permanen (tetap) yang menyatakan sifat, keadaan dan sebagainya, misalnya tutup kepala peci merupakan tanda pengenal tutup kepala nasional Indonesia (Herusatoto, 2008:17).

Simbol atau lambang adalah sesuatu hal atau keadaan yang merupakan pengantara pemahaman terhadap objek. Dan untuk mempertegas pengertian simbol atau lambang ini perlu dibedakan antara pengertian-pengertian seperti isyarat, tanda dan simbol atau lambang. Isyarat ialah sesuatu hal atau keadaan yang diberitahukan kepada si subjek kepada objek, artinya subjek selalu berbuat sesuatu untuk memberitahukan kepada si objek yang diberi isyarat agar si objek mengetahuinya pada saat itu juga.

Isyarat tidak dapat ditangguhkan pemakaiannya, ia hanya berlaku pada saat dikeluarkan atau dilakukan oleh subjek. Isyarat yang dapat ditangguhkan atau disimpan penggunaannya akan berubah bentuknya menjadi tanda. Contoh isyarat misalnya bunyi peluit kereta api, gerakgerak bendera morse atau bunyi peluit dari pandu. Tanda ialah sesuatu hal atau keadaan yang menerangkan atau memberitahukan objek kepada si subjek ; sedangkan simbol atau lambang ialah sesuatu hal atau keadaan yang memimpin pemahaman si subjek kepada objek.

Tanda selalu menunjuk pada sesuatu yang riil (nyata) yaitu benda, kejadian atau tindakan. Tanda-tanda yang dibuat oleh manusia pun menunjukkan sesuatu yang terbatas artinya dan menunjukkan hal-hal tertentu, misalnya tanda-tanda lalu lintas. Sebaliknya pada lambang, merupakan sesuatu benda, keadaan atau hal yang mempunyai arti lebih luas dan memerlukan pemahaman subjek akan arti yang terkandung di dalam lambang-lambang tersebut.

Merupakan sesuatu yang tidak dapat dipungkiri bahwa setiap orang membutuhkan hubungan sosial dengan orang-orang disekitarnya dan kebutuhan tersebut terpenuhi melalui pertukaran pesan yang berfungsi sebagai jembatan untuk mempersatukan manusia-manusia yang tanpa berkomunikasi akan terisolasi. Pesan-pesan itu disampaikan melalui beberapa perilaku manusia misal ketika kita melambaikan tangan, tersenyum,bermuka masam, menganggukan a tau menggelengkan kepala dan lain sebagainya.

Budaya merupakan warisan turuntemurun dari generasi ke generasi, salah satu upacara tradisional yang masih diyakini serta dilestarikan oleh masyarakat Jawa yaitu Sadranan. Sebuah tradisi yang sampai saat ini masih kental dengan mempercayai simbol-simbol tradisi leluhur ini telah mewarnai kehidupan masyarakat di sekitarnya. Keberadaan budaya tradisional ini diharapkan tidak akan mengalami pergeseran, dikarenakan kebudayaan ini merupakan salah satu upaya pelestarian amanat leluhur dan sebagai pengukuhan nilai-nilai budaya yang berlaku turun temurun secara simbolik. Dengan demikian simbolisme dalam masyarakat tradisional disamping membawakan pesan-pesan kepada 
generasi-generasi berikutnya juga selalu dilaksanakan dalam kaitannya dengan religi.

Tradisi Sadranan yang dilakukan tiap bulan ruwah ini sangat ramai diadakan diberbagai wilayah suku Jawa, salah satunya di Desa Karangturi, Kecamatan Gantiwarno, Kabupaten Klaten. Tiap wilayah telah memiliki ketentuan masingmasing mengenai waktu pelaksanaan tradisi Sadranan ini. Masyarakat desa Karangturi, Kecamatan Gantiawarno, Kabupaten Klaten, rutin melaksanakan tradisi Sadranan setiap tanggal 24 Ruah atau tanggal jawa pada tiap tahunnya.

Bukan hanya orang tua saja yang berperan, pemuda-pemudi pun turut andil dalam meramaikan upacara tersebut. Hal inilah yang menunjukkan budaya masyarakat guyub rukun, gotong-royong, dan kekeluargaan. Dalam tradisi Sadranan ini sarat dengan adanya simbol-simbol yang berfungsi sebagai media komunikasi untuk menitipkan suatu pesan di dalamnya. Sebagai sebuah media komunikasi, upacara tradisi Sadranan pasti memiliki serangkaian prosesi yang diwakilkan melalui simbolsimbol untuk menyampaikan suatu pesan pada generasi penerusnya. Hal tersebut memunculkan pertanyaan di benak penulis mengenai "bagaimana tahapan-tahapan awal sampai akhir dari prosesi upacara Sadranan, simbol-simbol seperti apa yang digunakan sebagai media komunikasi, apa nilai-nilai yang terkandung dalam tradisi Sadranan tersebut, serta pesan apa sebenarnya yang ingin disampaikan?"

Disamping itu tradisi Sadranan ini juga merupakan warisan dari generasi ke generasi yang sampai saat ini masih mempengaruhi kehidupan masyarakat desa Karangturi, Kecamatan Gantiwarno, Kabupaten Klaten. Melihat kajian Ilmu Komunikasi, kebudayaan sangat kurang dijadikan sebagai bahan penelitian oleh mahasiswa, khususnya mahasiswa FISIP Ilmu Komunikasi. Mahasiswa cenderung lebih tertarik untuk mengambil penelitian pada bidang iklan, film, televisi dan radio.

Penulis merasa perlu untuk mengangkat penelitian mengenai upacara tradisi Sadranan sebagai salah satu upaya dalam melestarikan upacara adat ini. Mengingat semakin maraknya budaya modern yang berkembang luas serta gaya hidup masyarakat yang semakin maju, namun nyatanya tradisi Sadranan ini masih tetap dilaksanakan oleh suku Jawa secara rutin tiap tahun khususnya masyarakat desa Karangturi Kecamatan Gantiwarno, Kabupaten Klaten. Di samping itu, penulis juga ingin memperkenalkan kebudayaan atau tradisi masyarakat Desa Karangturi kepada masyarakat luas, agar masyarakat luas mengetahui jenis, simbol-simbol yang digunakan sebagai media komunikasi, dan nilai-nilai yang terkandung dalam prosesi upacara tradisi Sadranan.

Dengan mengangkat tema tradisi Sadranan ini mampu memberi pengetahuan kepada masyarakat luas mengenai kebudayaan yang mungkin selama ini kurang diperhatikan secara khusus oleh sebagian besar masyarakat sehingga dapat menambah wawasan budaya khususnya di daerah pedesaan dan menjadikannya sebagai sarana untuk diadakannya komunikasi antar masyarakat dalam meningkatkan perkembangan budaya.

Masyarakat luas mungkin sudah mengetahui tentang upacara tradisi Sadranan sebatas sebuah kebiasaan ziarah kubur yang di balut dengan adat yang dilakukan pada setiap bulan syawal. Akan tetapi penulis yakin tidak banyak masyarakat yang mengetahui secara detail mengenai tahapan-tahapan prosesi upacara tradisi Sadranan, seperti apa persiapan yang dilakukan, simbol-simbol apa saja yang digunakan sebagai media komunikasi serta apa sebenarnya isi dari pesan yang disampaikan. Untuk itu penulis merasa tertarik untuk meneliti secara mendalam mengenai prosesi upacara tradisi Sadranan $\mathrm{u} \mathrm{n} \mathrm{uk}$ melestarikan d a n 
Metode Penelitian

Jenis penelitian yang digunakan dalam penelitian ini adalah penelitian deskriptif kualitatif. Penelitian ini memaparkan situasi atau peristiwa, tidak mencari hubungan, tidak menguji hipotesa atau membuat prediksi. Sementara perolehan data kualitatif tidak dipandu oleh teori, tetapi dipandu oleh fakta-fakta yang ditemukan pada saat penelitian di lapangan. Metode kualitatif digunakan untuk mendapatkan data yang mendalam, suatu data yang mengandung makna. Makna adalah data yang sebenarnya, data yang pasti yang merupakan suatu nilai di balik data yang tampak. Penelitian kualitatif lebih menekankan pada makna (Sugiyono, 2007: 3).

Pada penelitian ini, penulis memberikan uraian tentang makna yang terkandung dalam prosesi tradisi Sadranan di Desa Karangturi, Kecamatan Gantiwarno, Kabupaten Klaten. Penulis akan memaparkan dan mendeskripsikan seluasluasnya tentang tahapan-tahapan pada prosesi tradisi Sadranan berdasarkan pada observasi, dokumentasi, wawancara, dan studi pustaka. Setelah seluruh data dari berbagai sumber terkumpul, penulis akan mengolah data-data tersebut melalui metode reduksi data, sajian data, membahas dan menarik kesimpulan, serta melakukan triangulasi sumber untuk mengetahui makna-makna yang terkandung dalam prosesi upacara tradisi Sadranan.

Validitas data yang digunakan dalam penelitian berupa derajat ketepatan antara data yang terjadi pada objek penelitian dengan hasil yang diperoleh oleh peneliti, sehingga hasil penelitian dapat diuji keabsahannya berdasarkan- dengan apa yang terjadi pada objek sesuai dengan hasil yang diperolehnya. Untuk menjamin validitas data atau keabsahan data diperlukan teknik pemeriksaan. Dalam penelitian kualitatif, data dapat dinyatakan valid apabila tidak ada perbedaan antara yang dilaporkan peneliti dengan apa yang sesungguhnya terjadi pada objek yang diteliti. Teknik triangulasi yang digunakan dalam penelitian ini adalah peneliti menggunakan beberapa sumber data untuk mengumpulkan data yang sama, dengan tujuan untuk memberikan kebenaran, untuk memperoleh kepercayaan terhadap suatu data dengan membandingkan data yang diperoleh dari sumber yang berbeda.

Nilai dari teknik pengumpulan data dengan triangulasi adalah untuk mengetahui data yang diperoleh convergent (meluas), tidak konsisten atau kontradiksi. Dengan menggunakan teknik triangulasi dalam pengumpulan data, maka data yang diperoleh akan lebih konsisten, tuntas dan pasti. Peneliti mengumpulkan data yang sekaligus menguji kredibilitas data dengan berbagai teknik pengumpulan data dan berbagai sumber data. Melalui triangulasi akan lebih meningkatkan kekuatan data, bila dibandingkan dengan satu pendekatan.

\section{Hasil Penelitian dan Pembahasan}

Upacara Sadranan yang dilaksanakan setiap tanggal 24 ruwah menjelang bulan puasa pada intinya tak jauh beda dengan ritual serupa di waktu lain dalam penanggalan Jawa seperti Suranan, Muluran, atau Syawalan. Intinya adalah memanjatkan doa kepada Tuhan Yang Maha Esa agar diberi keselamatan dan kesejahteraan. Sebuah ritual doa menggunakan media yang dipercaya masyarakat dapat mendekatkan diri mereka dengan Tuhan Yang Maha Esa. Sadranan menjelang bulan puasa selain memiliki makna doa kepada Tuhan Yang Maha Esa, juga merupakan suatu penghargaan terhadap bulan Syakban (Jawa : Ruwah), bulan yang memiliki keistimewaan.

Tradisi Sadranan ini tetap dipertahankan tetapi substansinya diisi dengan nilai-nilai Islam. Sadranan tidak lagi dipersembahkan kepada arwah leluhur, tetapi merupakan sarana atau media untuk 
sedekah serta mendoakan agar arwah para leluhur bisa tentram, damai di sisi Allah SWT. Sesaji yang semula berupa makanan mentah, daging mentah dan darah kini diganti dengan makanan dan minuman yang baik, yang disesuaikan dengan kemampuan dari masing-masing kepala keluarga. Rangkaian Sadranan ini dilaksanakan dengan berbagai variasi sesuai dengan adat masing-masing daerah mengingat tradisi Sadranan ini telah ada di berbagai wilayah Jawa Tengah. Pada umumnya tradisi Sadranan diawali dengan bersih-bersih makam. Acara bersih kubur ini merupakan kegiatan pembuka dan melibatkan seluruh masyarakat desa. Setelah gotong-royong bersih-bersih makam, kegiatan dilanjutkan dengan membersihkan jalan-jalan, balai desa atau tempat lainnya yang memiliki fungsi sebagai tempat publik.

Tradisi upacara Sadranan dilaksanakan sesuai dengan tata cara pelaksanaan yang telah disepakati oleh tetua adat dan masyarakat Desa Karangturi pada setiap tahunnya. Tradisi upacara Sadranan ini dilaksanakan satu tahun sekali yang melibatkan seluruh masyarakat Desa Karangturi, Kecamatan Gantiwarno, Kabupaten Klaten yang dikoordinir oleh Pak Kaur selaku perwakilan dari kantor kecamatan Desa Karangturi. Dalam event upacara Sadranan ini, Masyarakat Desa Karangturi mengikuti serangkaian kegiatan yang terangkum dalam tata cara pelaksanaan upacara Sadranan yang meliputi: (1) Pra-upacara Sadranan (2) Hari$\mathrm{H}$ upacara Sadranan (3) Acara Kenduri. Serangkaian kegiatan tersebut dilakukan secara bertahap dalam kurun waktu yang berdekatan.

Bentuk komunikasi sosial dari tradisi upacara Sadranan ini adalah penyampaian pesan atau nasehat dari orang-orang tua zaman dahulu kepada generasi mudanya agar tetap hormat kepada arwah nenek moyang atau leluhurnya yang diharapkan berimbas kepada menghormati orang tua yang masih hidup. Disamping itu, komunikasi sosial juga tampak ketika warga masyarakat Desa Karangturi menunjukkan aktualisasi dirinya sebagai bentuk eksistensi dengan mengikuti prosesi upacara Sadranan. Hal tersebut merupakan suatu keinginan untuk menunjukkan diri bahwa mereka pun ada dan turut aktif mengikuti rangkaian kegiatan upacara Sadranan.

Masyarakat Desa Karangturi juga menunjukkan rasa nyaman, tenteram,saat berbaur tanpa terhalang oleh perbedaan kelas sosial dengan warga lainnya, dimana hal tersebut mengisyaratkan bahwa komunikasi sosial dilakukan untuk pemenuhan diri untuk merasa terhibur pada saat memupuk hubungan baik dengan sesama. Upacara Sadranan juga dijadikan sebagai wahana pergaulan sosial dimana terjadi penyampaian informasi yang melibatkan seluruh lapisan warga masyarakat Desa Karangturi. Upacara Sadranan merupakan salah satu bentuk komunikasi sosial yang memiliki makna berupa keselarasan atau sebuah harmoni yang tercipta dalam dinamika kehidupan warga masyarakat Desa Karangturi.

Harmoni sosial tampak begitu nyata dalam perilaku hidup sehari-hari warga masyarakat Desa Karangturi. Upacara Sadranan pun memiliki peranan penting dalam menciptakan harmoni sosial pada kehidupan masyarakat Desa Karangturi. Kerja bakti bersih makam merupakan salah satu simbol dari harmoni sosial dimana terdapat guyub rukun, gotong royong, serta nuansa kekeluargaan yang sangat kental. Melalui harmoni sosial inilah tercipta suatu bentuk keselarasan yang berujung pada kesejahteraan bersama dalam hidup bermasyakat. Bagi orang Jawa keselarasan sosial atau keharmonisan merupakan sebuah rangkaian besar terjadinya kesejahteraan hidup bersama. Karena kesejahteraan terikat secara mutlak pada keselarasan sosial, antara sesama yang illahi, 
alam dan sesama manusia.

Pada saat penelitian, penulis berhasil menemukan fakta baru dan berhasil mengidentifikasikan mengenai terjadinya pergeseran nilai-nilai yang terkandung di dalam prosesi upacara Sadranan. Temuan fakta baru ini bermula ketika penulis sedang mewawancarai Kepala Desa Karangturi, Kecamatan Gantiwarno, Kabupaten Klaten, Bapak Sarno. Beliau mengemukakan bahwa ada beberapa perubahan serta perubahan makna dengan upacara Sadranan zaman dahulu, dengan upacara Sadranan msa sekarang. Sadranan pada zaman dahulu terdapat berbagai sesaji yang memang diperuntukkan bagi arwah para leluhur atau nenek moyang. Sesaji berupa makanan mentah, daging mentah, dupa dan darah itu diperuntukkan bagi para arwah leluhur agar masyarakat mendapat keselamatan, kesejahteraan, dan keberkahan hidup.

Sedangkan upacara Sadranan pada masa sekarang tetap mempertahankan substansinya namun telah diisi dengan nilai-nilai Islam. Sadranan tidak lagi dipersembahkan kepada arwah para leluhur atau nenek moyang, namun merupakan sarana atau media untuk sedekah serta mendoakan arwah leluhur agar bisa tentram. Sesaji yang semula berupa makanan mentah, daging mentah dan darah pun sekarang telah diganti dengan makanan dan minuman yang baik. Tradisi upacara Sadranan telah mengalami pergeseran nilai dan makna yakni sebagai ziarah kubur mendoakan arwah leluhur agar memperoleh ketentraman di sisi Allah SWT.

Penulis merasa bahwa fakta ini merupakan suatu fenomena yang lazim terjadi sebagai wujud dari sifat-sifat kebudayaan yang tidak 100 persen statis, karena jika kebudayaan 100 persen statis tanpa dinamika, maka kebudayaan dapat dikatakan mati saja. Begitu pula tradisi upacara Sadranan.

Hal tersebut juga berkaitan dengan komunikasi. Baik secara langsung maupun tak langsung, tradisi upacara Sadranan ini memiliki fungsi komunikasi kultural dimana budaya menjadi bagian dari perilaku komunikasi, dan pada gilirannya komunikasi pun turut menentukan, memelihara, mengembangkan atau mewariskan budaya. Tradisi Upacara Sadranan di Desa Karangturi ini merupakan salah satu warisan budaya dari nenek moyang atau leluhur yang sampai saat ini masih rutin dilaksanakan tiap tahunnya.

\section{Simpulan}

Tradisi upacara Sadranan mengalami pergeseran makna. Sadranan tidak lagi dimaknai sebagai sebuah ritual untuk memohon keselamatan serta berkah dari arwah para leluhur, melainkan upacara Sadranan dipandang sebagai media untuk memanjatkan doa keselamatan para leluhur sebagai perwujudan dinamika kebudayaan yang tidak 100 persen bersifat statis.

Bentuk komunikasi sosial dari tradisi upacara Sadranan ini adalah penyampaian pesan atau nasehat dari orang-orang tua zaman dahulu kepada generasi mudanya agar tetap hormat kepada arwah nenek moyang atau leluhurnya yang diharapkan berimbas kepada menghormati orang tua yang masih hidup. Selain itu dalam upacara Sadranan ini terdapat bentuk aktualisasi diri masyarakat sebagai wujud eksistensi diri dalam aktivitas sosial, serta memupuk hubungan yang baik antar warga. Tradisi upacara Sadranan mengandung harmoni sosial yang memiliki peranan penting dalam menciptakan keharmonisan hidup bermasyarakat di Desa Karangturi, Kecamatan Gantiwarno, Kabupaten Klaten.

\section{Daftar Pustaka}

Andry, Jonathan. (2010). Upacara Adat Naik Dango Sebagai Sebuah Simbol Komunikasi, Skripsi, Universitas Pembangunan Nasional "Veteran" Yogyakarta, Yogyakarta, Indonesia. 
Fajar, Marhaeni. (2009). Ilmu Komunikasi Teori dan Praktik. Yogyakarta: Graha Ilmu.

Herusasoto, Budiono. (2001). Simbolisme Dalam Budaya Jawa. Yogyakarta: Hanindita.

Herimanto dan Winarno. (2008). Ilmu Sosial dan Ilmu Budaya Dasar. Solo: Bumi Aksara.

Ihromi, T. O. (2003). Pokok-pokok Antropologi Budaya. Jakarta: Yayasan Obor Indonesia.

Littlejohn, Stephen W. (1999). Theories Of Human Communication. California: Sixth edition, Wadsworth Publishing Company.

Littlejohn, Stephen W. (2009). Teori Komunikasi Theories of Human Communication. Jakarta: Salemba Humanika.

Mulyana, Deddy. (2007). Ilmu Komunikasi Suatu Pengantar. Bandung: Rosdakarya.
Mulyana, Deddy. (2008). Metodologi Penelitian Kualitatif. Bandung: Rosdakarya.

Prasetya, J. T. (1991). Ilmu Budaya Dasar. Jakarta: Rineka Cipta.

Sulaeman, Munandar. (1992). Ilmu Budaya Dasar Suatu Pengantar. Bandung: Eresco.

Sobur, Alex. (2003). Semiotika Komunikasi. Bandung: Rosdakarya.

Sugiyono. (2007). Memahami Penelitian Kualitatif. Bandung: Alfabeta.

Tubbs, S. L. dan Silvia, Mosi. (2001). Human Communication Prinsip-Prinsip Dasar. Bandung: Rosdakarya.

Widagdho, Djoko (1991). Ilmu Budaya Dasar. Jakarta: Bumi Aksara.

\section{Website}

Kompas.com/kompasiana.

http://www.klaten.go.id/geografi.shtml. 